
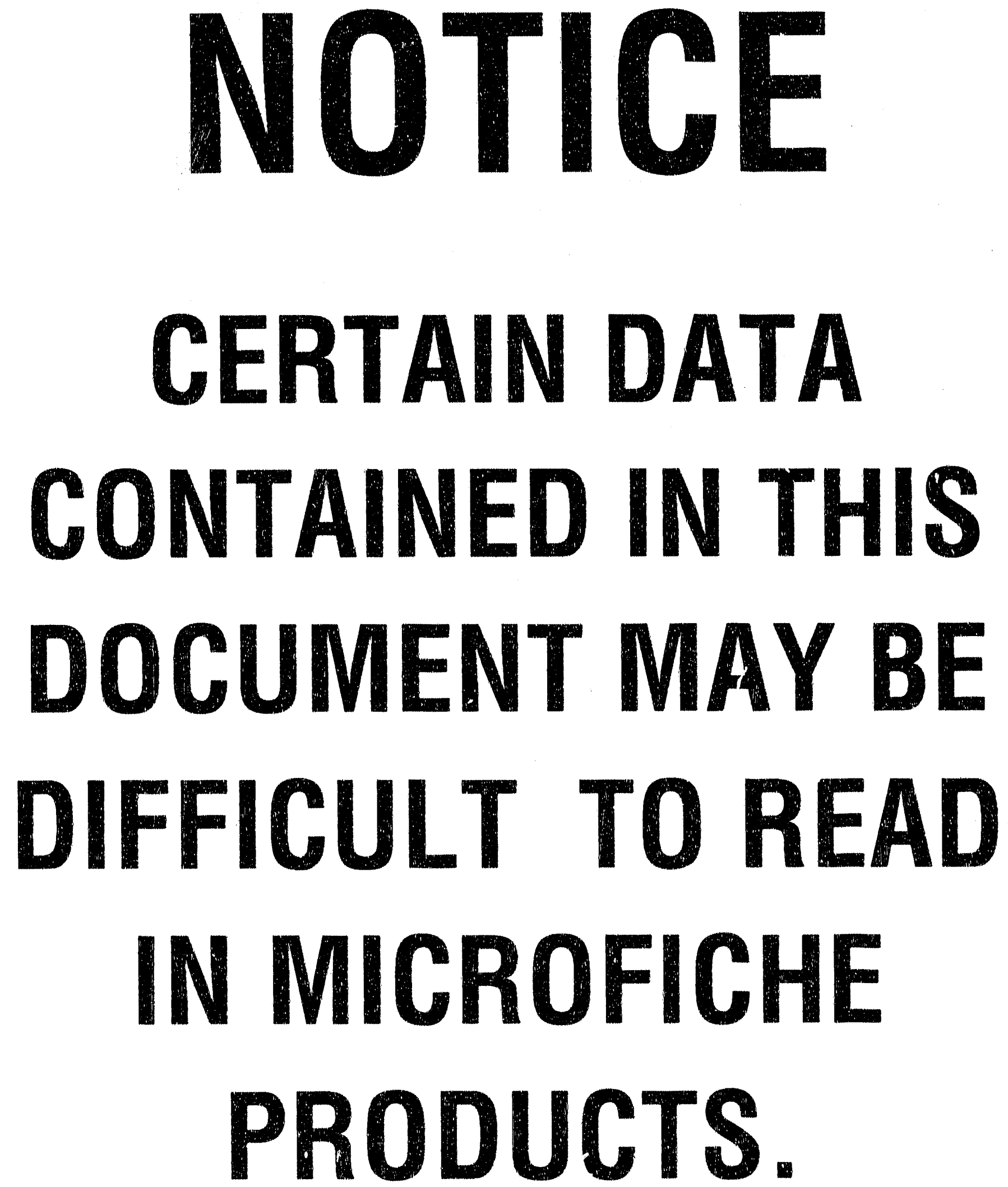


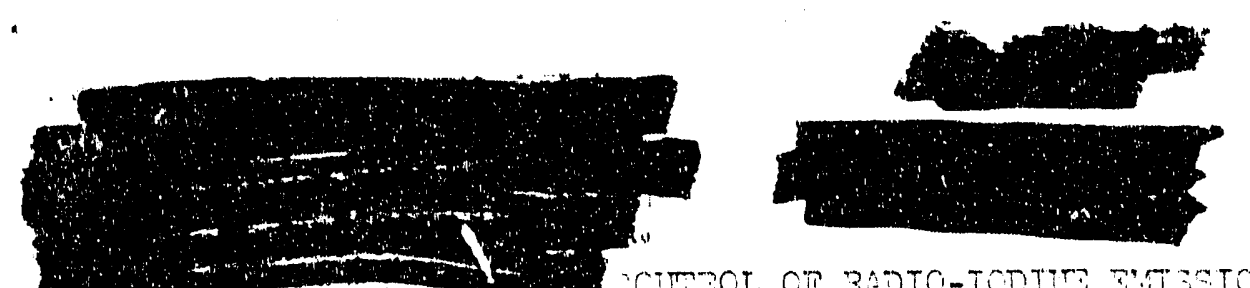

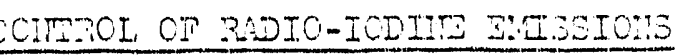

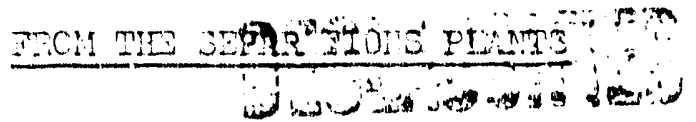
$H W--69074-R D$ DE92 019145

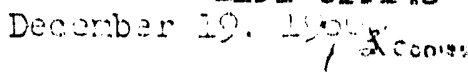
Distrinetion:

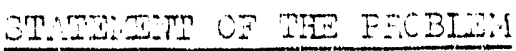

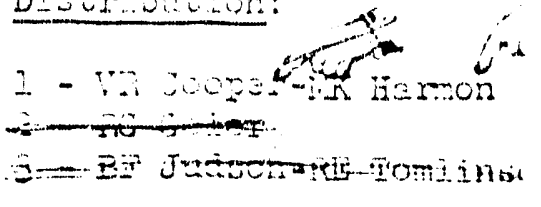

The relesse of radio-iodine from the irradiated uraniun durias dissolution, and

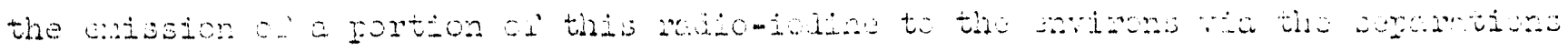
- and

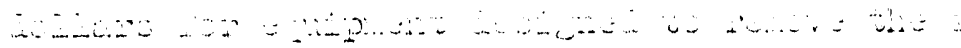

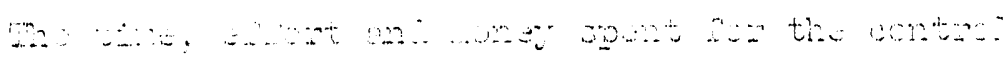

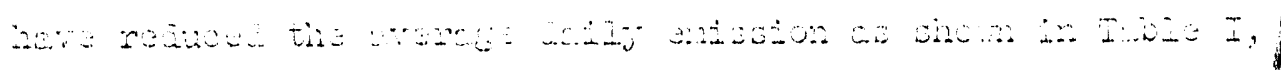

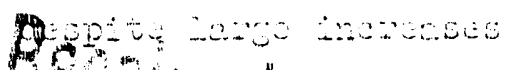

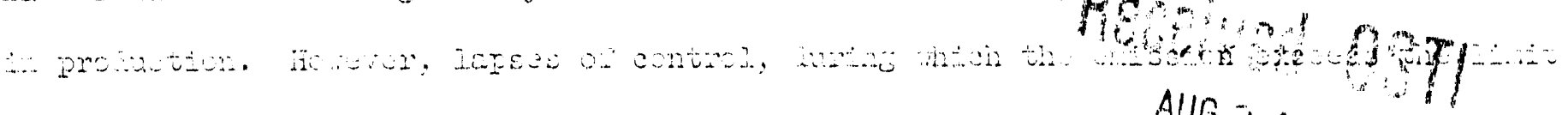

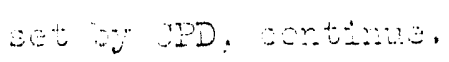

$$
\text { AUG } 241992
$$

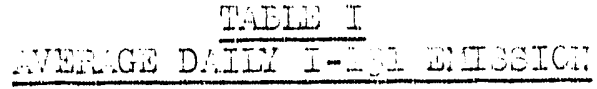

$\because 02012$

January

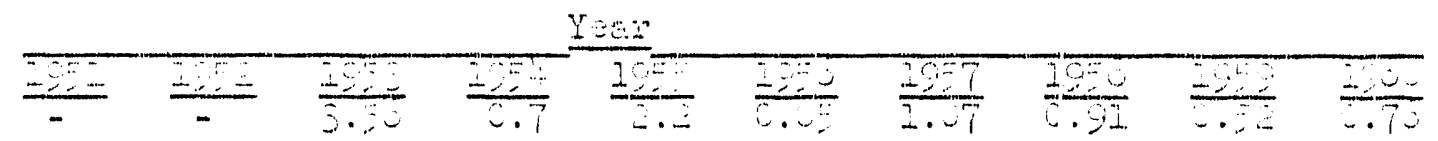

Feomary

ision

$$
2.23
$$

$\therefore i$

$j \cdot \pi \quad 2.0$

1.5工 1.75

$0 .=0 \quad \therefore .50$

Apriz

$\therefore 31$

$3.0 \quad 2 \% .6$

o.

$2.13 \quad 3.57$

0.30 .23

lis

$20.2-3.36$

2.2

2.12 .57

1.09

1.2工

I. 250.50

Jine

127

0.9

2.

2.00

6.50

.99

$0.9 \quad 0$.

28

$\therefore 2$

0.3

i. $=3.10$

0.5

0.50

$0.00 \quad 0.37$

Juis

$\therefore \because x=$

septoner

$+2=$

6.

I. . .

1.09

0.3

$0.5:$

3.58

cotoser

2.2

2.

2. :

$\therefore 2$

5.73

$\therefore .0$

0.7

0.29

1.

.

5




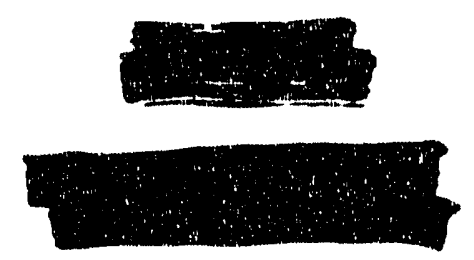

\section{HW 69064}

Pase 2

The allowable radio-iodine enission from the Chemical Processine Departinent separation plant stacks was set at ten curles per reek, with not more this three curies in any one day, in 1959. Adherence to this limit is expected to maintain the redio-iodine content of vegetation in the plant environs at less than $10-$

mico-o. e per gram o: "egetation.

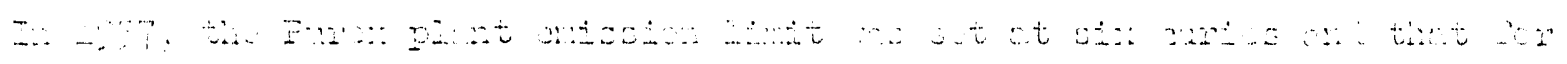

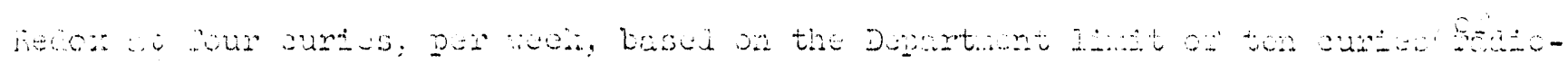

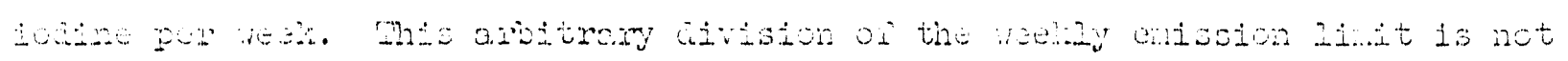

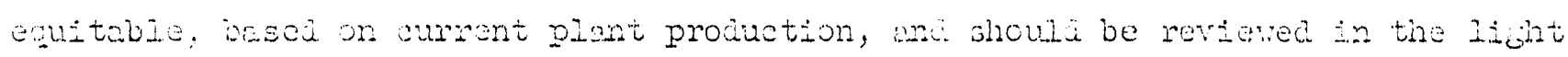

0. actur condition aw protuction schosules.

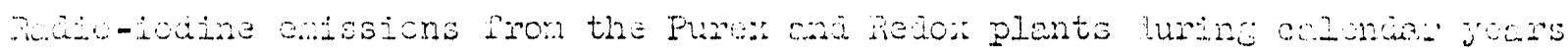

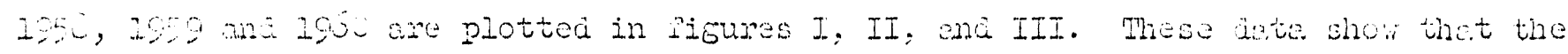

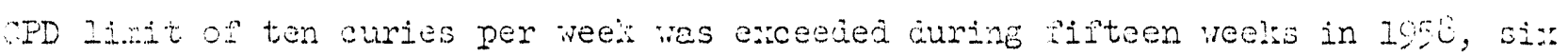
weis in 1959 , anj ten weeks in 1960. It should be remembered that in 1959 and 196, the Reco: plant processed wainiy lono-coolod J-motal.

A.though the weeliy enission linit has been exceded many times since it was etchlishad, only once has the Redox plant intermated aissolving operations becouse of iojine emission. This was from Decomber 21-23, 1950́, after emissions of

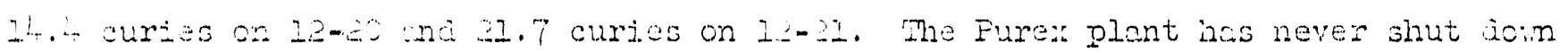

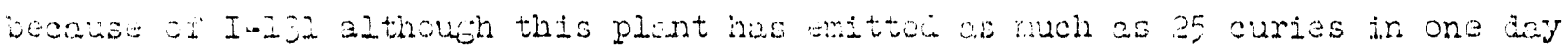

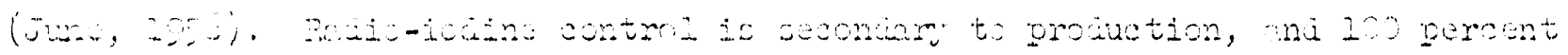
abanos to the CPD limit on tn curies per week is not expected. For example, the purex plont goal ior radio-iodine control (1960 and 1961) is "not to exceed the CPD limit nore than 3 times". The Redox plant goal is, "not to be the najor contributor to exceesing the CFD limit nore than it times", in 1950
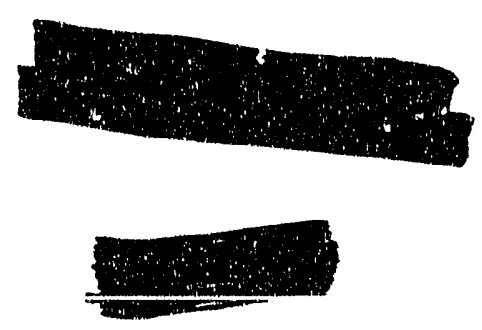

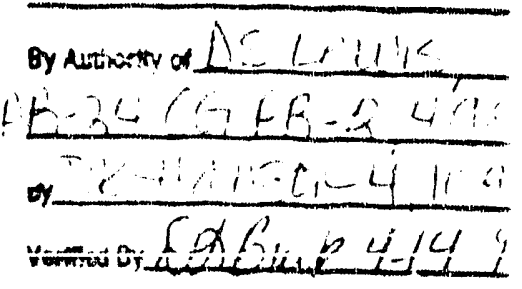


Future programs of the Irradiation Processine Department are all aimed at increasing the production firom the reactors. Past procrais have resulted in pile power levels of greater than $10 \mathrm{jr} / \mathrm{Ton}$ for depleted uraniun and oroatar than $\ln : \mathrm{T}$ lef or enrichod metal. Since the mio-iodine content of the irraiated antal at

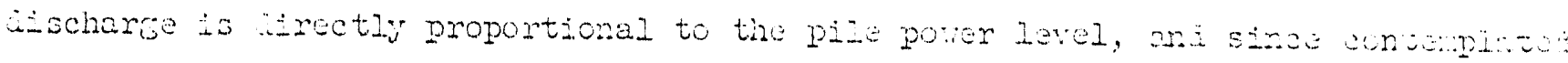

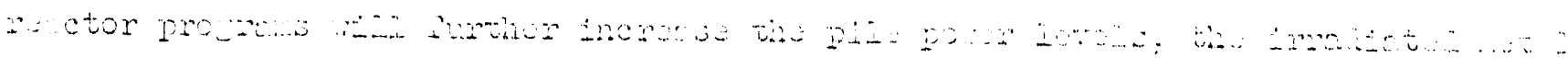

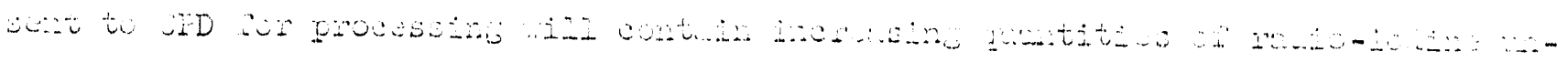

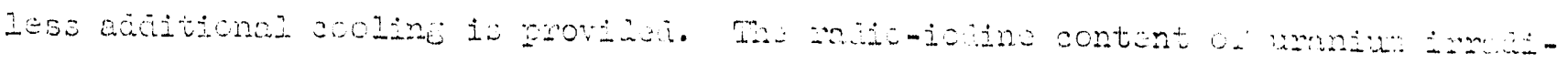

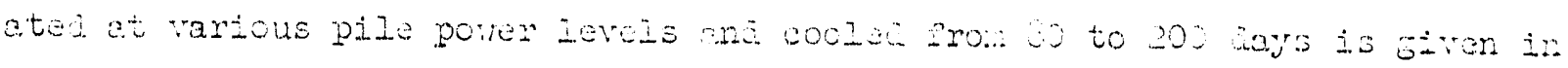
Xise II.

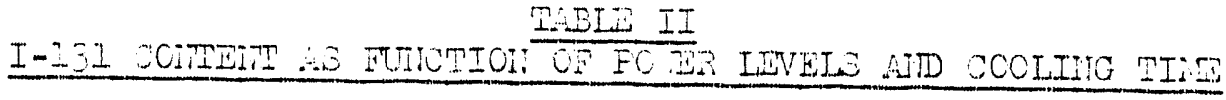

\begin{tabular}{|c|c|c|c|c|c|c|c|c|}
\hline \multirow{2}{*}{$\begin{array}{l}\text { Foner } \\
\text { Level, } \\
\text { mile } \\
\end{array}$} & \multirow{2}{*}{$\begin{array}{l}\text { Juries } \\
\text { I-IjI per } \\
\text { Ton U at } \\
\text { Discheree }\end{array}$} & \multicolumn{7}{|c|}{ Curies I-ijliton U Aiter cooling } \\
\hline & & 80 Days & 90 Days & 100 Days & 110 Days & 120 Doys & 15 Days & $200 \mathrm{Day}$ \\
\hline 2 & 47,600 & 47 & 20 & 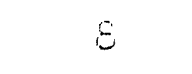 & 3.5 & 1.5 & 0.22 & 0.0014 \\
\hline 4 & 95,200 & 24 & 40 & $I 7$ & $7 \cdot 2$ & 3.0 & 0.22 & 0.0022 \\
\hline 6 & $1+2,800$ & 142 & 60 & 25 & 12 & $1+.5$ & 0.32 & 0.0043 \\
\hline $\mathrm{c}$ & 190,400 & 180 & 79 & 32 & Iit & $5 \cdot 9$ & $2 .+3$ & $0.00=7$ \\
\hline 10 & 236,00 & 235 & 90 & 42 & 10 & $7 . \div$ & $2.8+4$ & 0.0072 \\
\hline I: & 205,600 & 232 & 129 & 50 & 21 & 8.9 & $2.6:$ & 2.008 \\
\hline 24 & $3 \vdots \vdots: 200$ & 329 & 130 & 53 & $3:$ & 20.4 &. .75 & $\therefore 2000$ \\
\hline
\end{tabular}

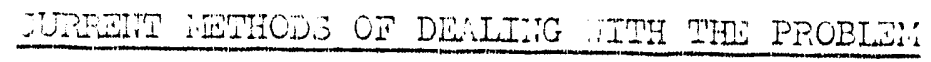

The primer weans of radio-iodine controi in the Redox plant is by passing dis-

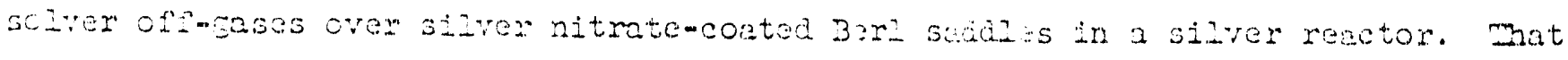
portion of rakio-icdine esceping tise izirer reactor is expected to be retained in the

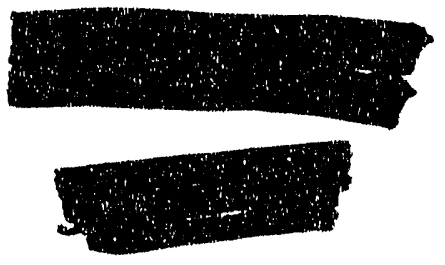


acid absorber or scmiber o. tire $293-3$, nitric acia recovery and iccine bachup

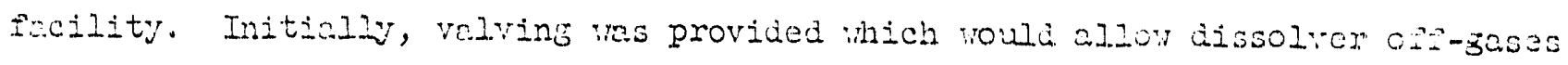
to i) completely by-pass the 29j-s Euilung, or i) pass through ioth the acid absorion and the caustic scrubber, on their ray to the ventilation staci. Ma

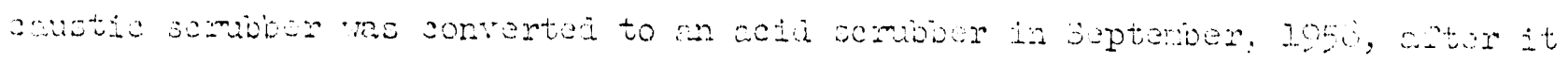

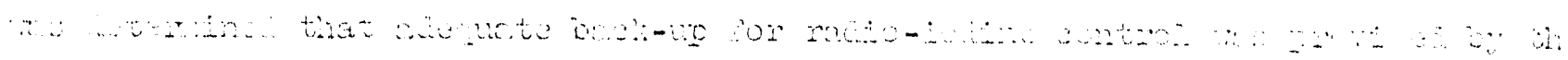

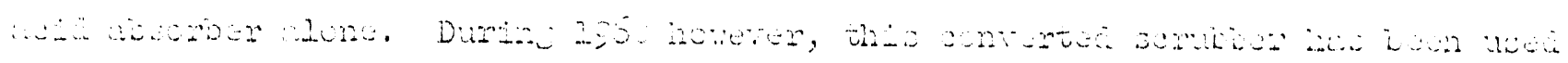

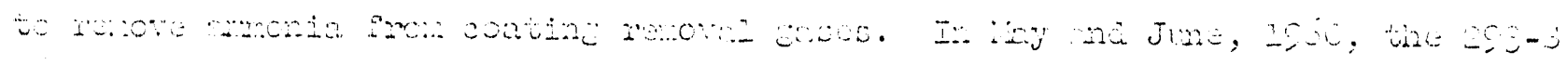

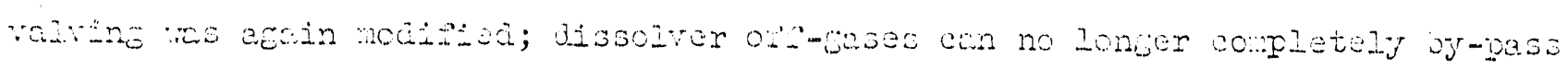

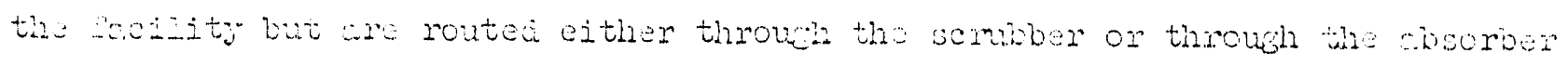
onu oemitor in erries.

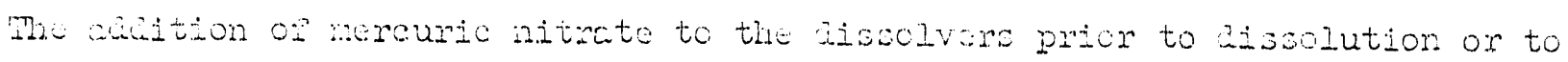

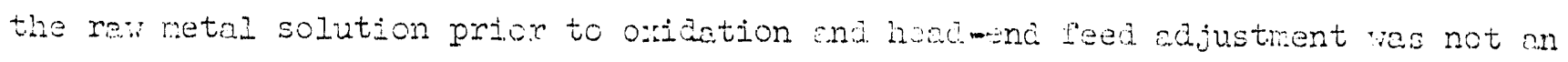
epective mons of rodio-iodine control at Redo: durine the short time it vas

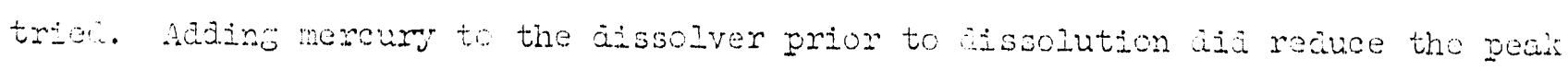
exission, but dia not reduce the over-all emission. Nercury adaition to the aissolver solution prior to oxidation showed little, if any, beneijt. Hovever, neither method has ever been fuily and fairly evaluated.

Couste semiber-type rabio-icaine nonitons were used intemittently for about

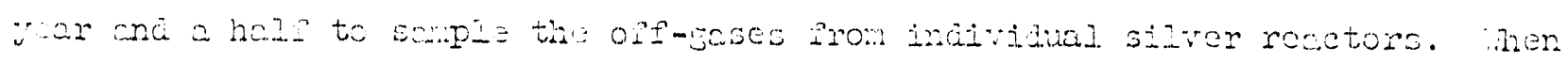

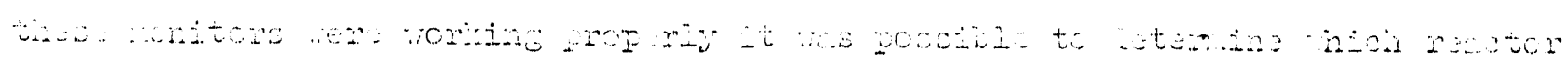

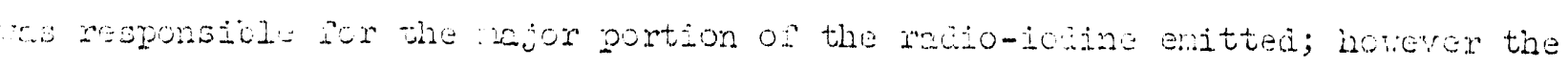
wanpover and antenance effort required to keep thom in operation was considered. excosire in relation to their function and their use was discontinued. Currentiy, cointillation counter at the stack indicate the mate at wich radio-icine is beinc mitted sompling at intermedate points is requided to determine the source. The
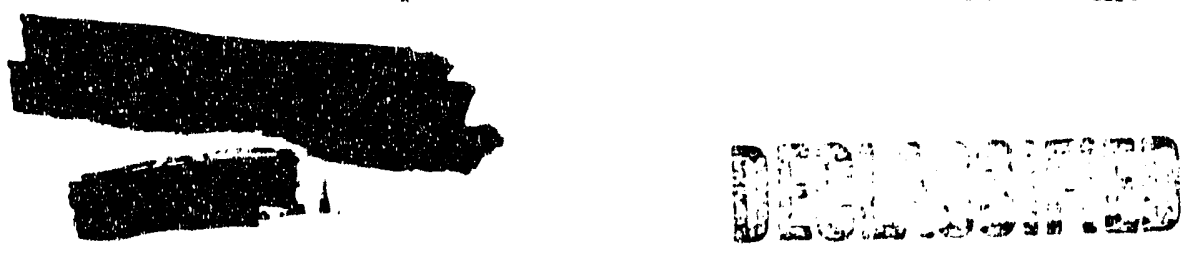


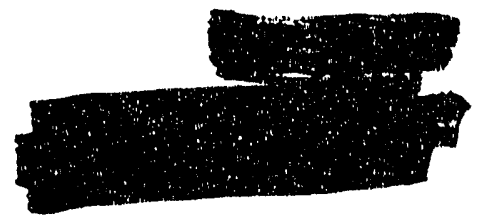

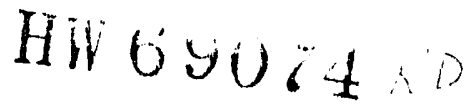

Päe 5

official data on duly radio-iodine emission wre based on the analysis or solution From a causto scrubber monitoring the gas laving through the plant ventilation

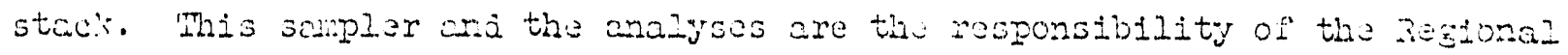
Yontaring Operation of the Radiation Frotection (peration of HIO.

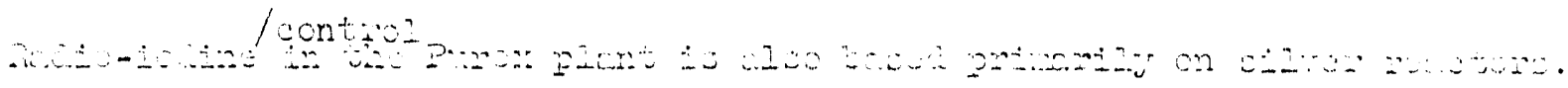

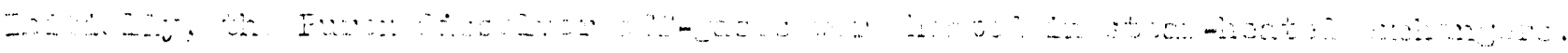

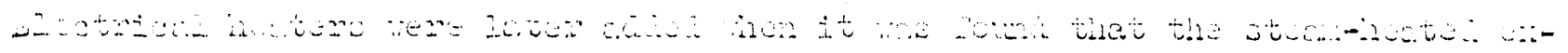

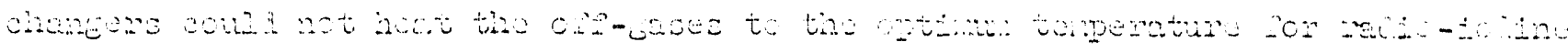

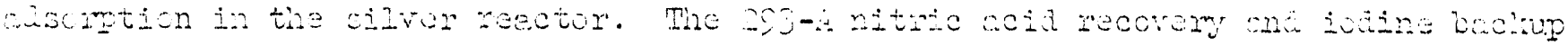

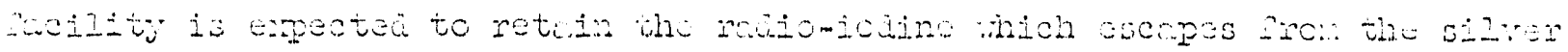

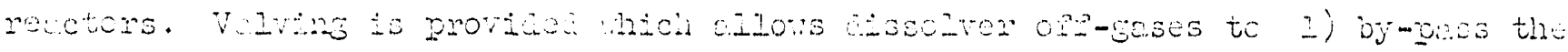

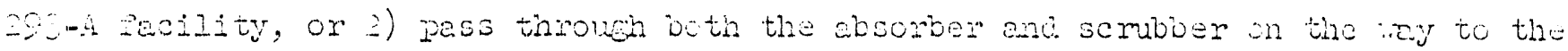
ventilation stack. The $293-A$ couctic acuboer res converted to ca ecid recovery semiboex eerly in 1950 . Amonia is removed from coating remal orfingase by a sembier in ech on the Lssonver celis.

The adistion of mercuric nitrate to nelie the feed solution 0.000 g lif $\mathrm{H}$ has been very effective in reducting the radio-iodine ewitted from the vessel vent system. Thenever uronium sooled less then 105 days is processed, the adation of nercuric nitrato recues the totel racio-iodine emission to the stack by a ractor or 2 to 4.

Ce--gases iron the ressel vent and condensen vent systems are router through

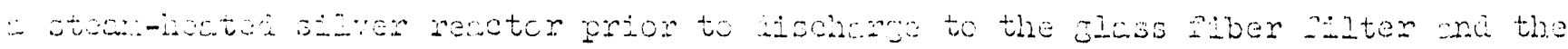
rentilation stack. The radio-ioline romoval eipteiency of this reactor does not aproach those in the dissolver cells since the off-seses connot be heated to the optinu reaction temperiture.

The ofucial inily radio-iodine emission from the Purex stacl: is determined in the sane waner as at Reriox. Seintillution counters have been installed to
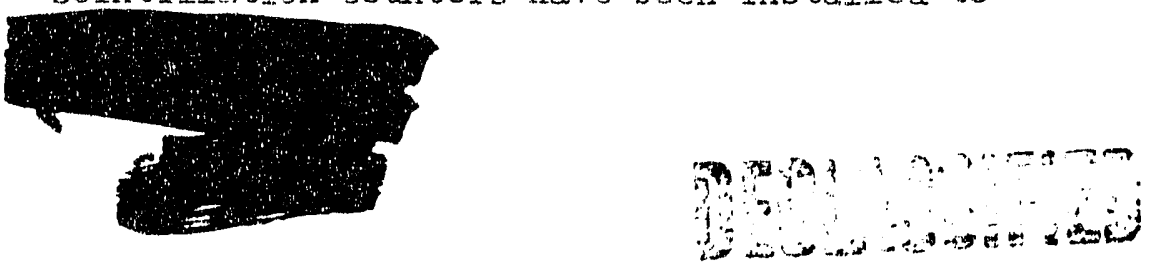

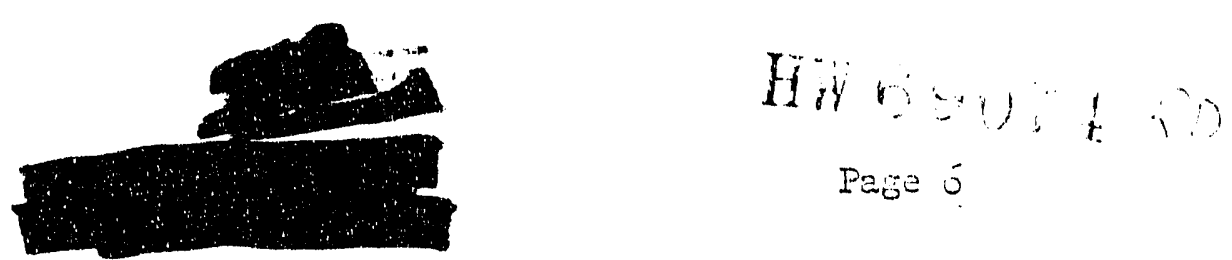

monitor the radio-iodine emission From the A and B reactors, C reactor, or from the $993-4$ fackity. These monitors are vely useful in determining the soures or a radio-iodine exission.

Radio-iojine control ts expensive. Some of the costs for radio-iouina control are shom in Fodz III.

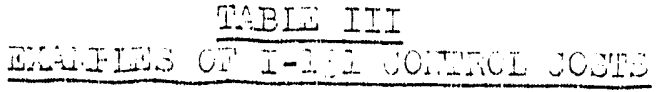

\section{$1+20200+2$}

Repati stom hestors

Aa electrion huturs

Frototipe and 2 apore reactors

Scintiliation-type :..onitors

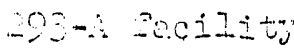

Airronia scrubbers

Regeneration chemicals 1950́-50

Juppression chemical, $\mathrm{H}_{5}\left(\mathrm{ITO}_{3}\right)_{2}$

$1950-1960$ est.

\section{Sesc: 0000}

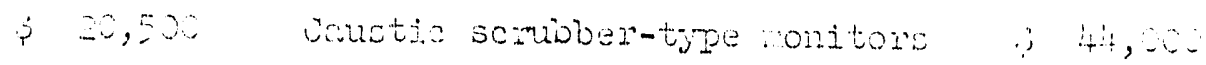

123,000 Reactors and heaters

$271, \infty$

IEt, 000 Isominetic samplen

40,000

75,000 Scintillation-type stack monitor

25,000

045,000

$293-3$ iacility

300,300

91,000 Regeneration chemicsls 1950-60

2,237

66,000 Frototype silver reactor

$$
\frac{60,000}{1,302,237}
$$

$\frac{30,000}{1,534,500}$

These costs do not incluje the cost of the original radio-iodine control equipment inctalied when the plants vere built nor do they include the very consideroule costs of associsted raseeroh and development, unvisul maintenonec and operoting problems (e.

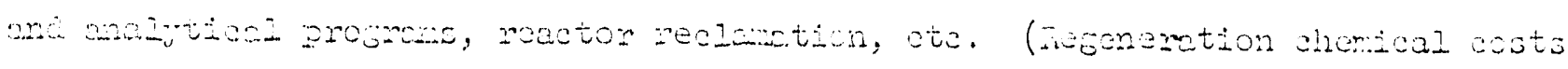
for Rodo: durins $1950-60$ are abnormally lo": because of processing long-cooled Z-notai.)

\section{IYIEES OF COITROI}

Athough large sums of acney have been spent for equipment and facilities iesioned to control radjo-iodine ewission, lapses oi cortrol continue. Durine the
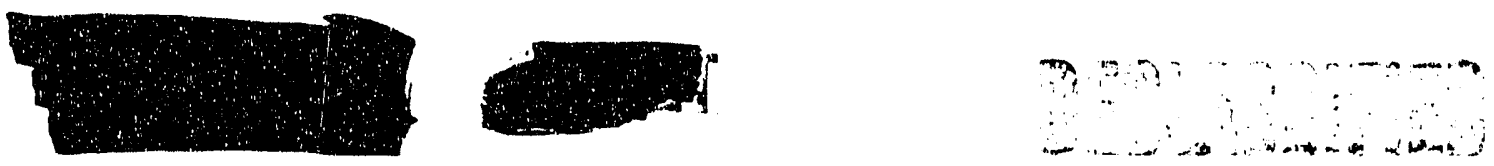


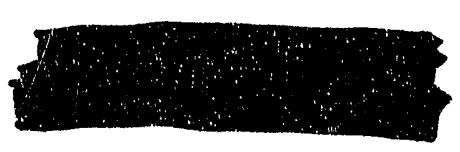

\section{HW 69064 id}

Page 7

past years, periods of abnomally hich emission from the Redo: plant have been attributed to:

1. Release of redio-iodine trapped in the silver reactor and/or the sand filter on several occasions during decontamination oi the conyon crone rith trichlorosthane.

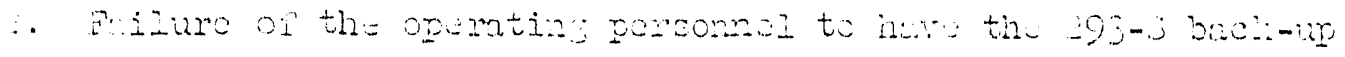

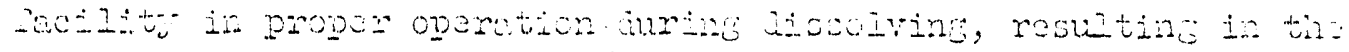
sporsing of rosio-icaine frow the said aboriven and celustio scmisber to the stick.

3. Aecicental shipuent of very "green" wetal by IPD ancits subsequent dissciuticn.

4. Inderictent radio-iodine renovel by the silver reactore coupida with leakine valves in the 293-s racizity, thus allovir.s the gases to by-pass absorber and scrubiber.

Aoncmally high redio-iodine smissions from the Purex plant have been caused by:

1. Boiling urcnium solution in a storage tanli, thus releasing approximately 20 curies of radio-iodine to the vessel vent system ihen a themohn failed. (Several other emissions from the vessel vent system have occurred because of near-boiling tempers.tures in reed and waste solutions.)

2. Disscluticn on short-cooles netel (20ss then go days).

3. Faizure to ada mercuric ion to matal solution from urenium cooled less than 105 days.

4. Loss of radio-icdine removal efficiency of the silver reactors torether with high dissolution rates currently attained.
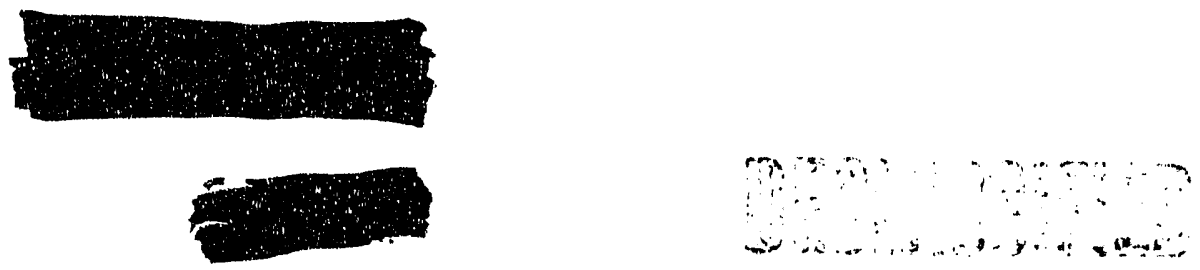


\section{AITERNLITE METHODS OF CONTROI}

\section{HW 69074}

Pege 8

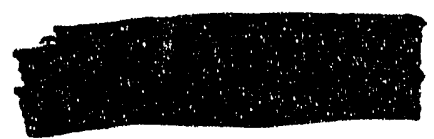

Since the current and past methols of controling the emission of rado-iodine have been neither complctely successtil nor holly dependable, acilitional control mecsures and/or alternate methods are required. Possibilities for improvement are:

1. Mrent all esluent ceses mon both Relo: end Pure:: to reworo

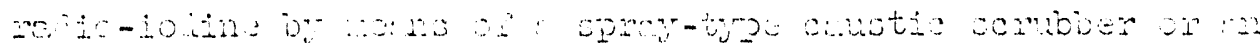

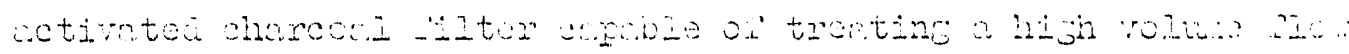

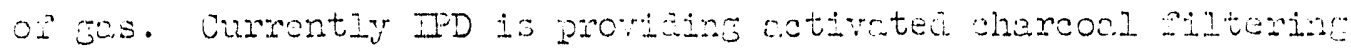

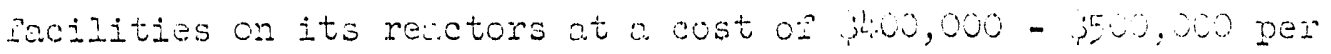
reactor. The air rolure to be trented is eror: 100,000 to $14, \ldots$, CTi per recotor. The cost os coustia scmbbers in eech building ns estimated to be approumetely 3 times the cost of activetad chareoal filters. It can be readily seen that treatment of all erfiuent geses from the Redox and Furex plonts vould be an expensive control measure.

2. Provide an electrically heated silver rector on the Purex vescel vent system in place or the presently installed steam-heated ractor, en electricelly heated silver reactor on the Redo: ressel vent syoten, and rectivation 0 the $293-\therefore$ and $293-3$ coustia scmubbers. Re-pipe so that by-passing $203-3$ and $293-A$ is physic-lily inpossible.

Cbjections have been mised regarding the safety hazard of an eloctrically heated reactor processing vessel vent gases containine orgenic vapors. These objections must be overcome or a unit dasigned which is approved for this semice. The cost of such a unit roula be $750,000-100,000$. Another $450,000-1100,000: 70 u 1 d$ be required to provide a silver reactor on the Redox vessel vent system. The

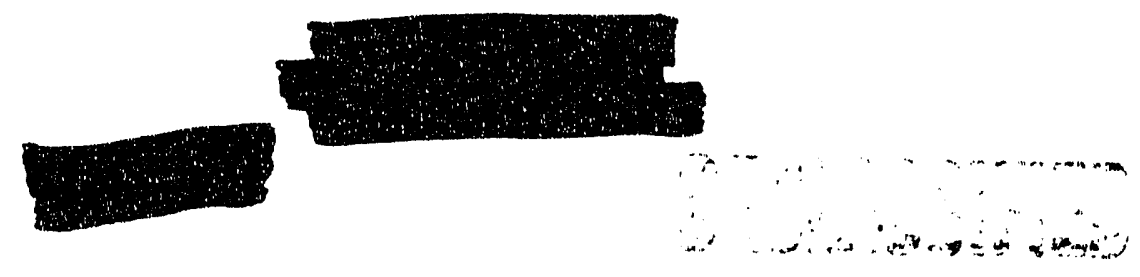




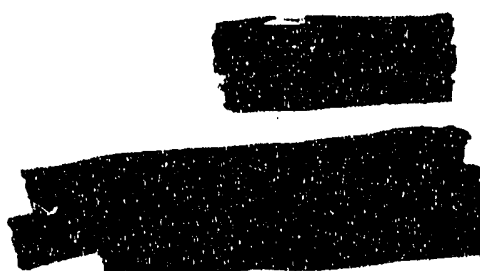

\section{$\mathrm{HW} 69064$}

costs to re-convert the caustic urubbers to caustic will be small; hovever, operation of these units wil cost the separations plants ij to w per ton of urnium processed.

3. Frovide net solia-state reactors or novel silver reactors ar

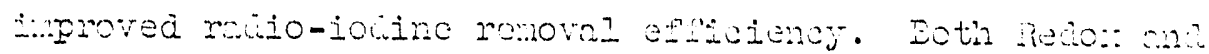

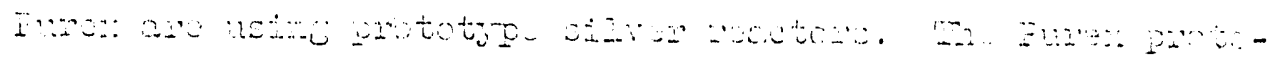

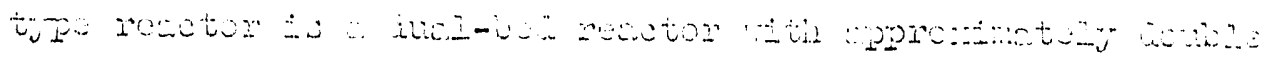

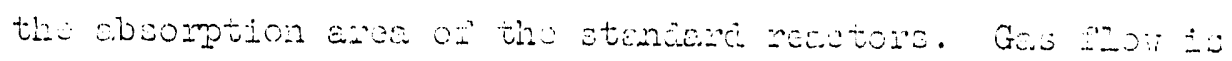

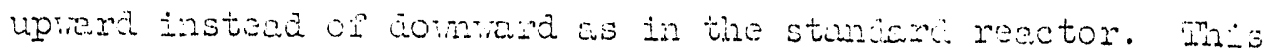

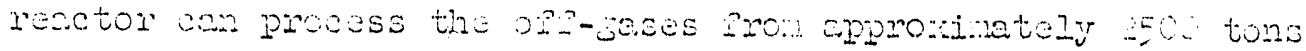

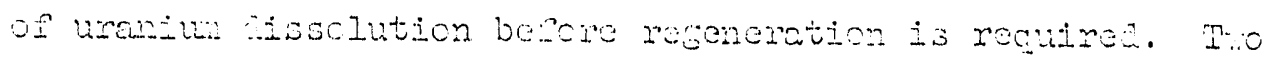

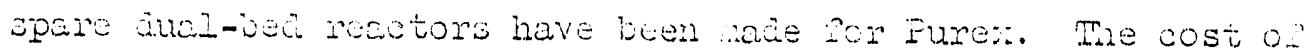
the prototjpe instaliation anc tro spare recetors was i164,000. The Redox prototype reactor has not been ally evaluated because of the preponderance of long-cooled I-metal in recent Redox operatine history. However, it is expected to process the offgases from the aissolution of several times nore uraniun then the standard reactors, before requiring regeneration. The cost or the Redox prototype instaliation as approximately $50,000$.

4. Frovide back-up racilities betieen the present $293-3$ and $29 j-A$

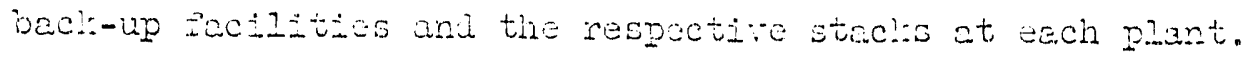
inother $; 200,000$ to is, 00,000 roula provile back-up caustic scrubbers.

The chief disadvantage of all of the above mentioned control messures is that they are subject to human or mechanical failure, and as a result cannot be expected
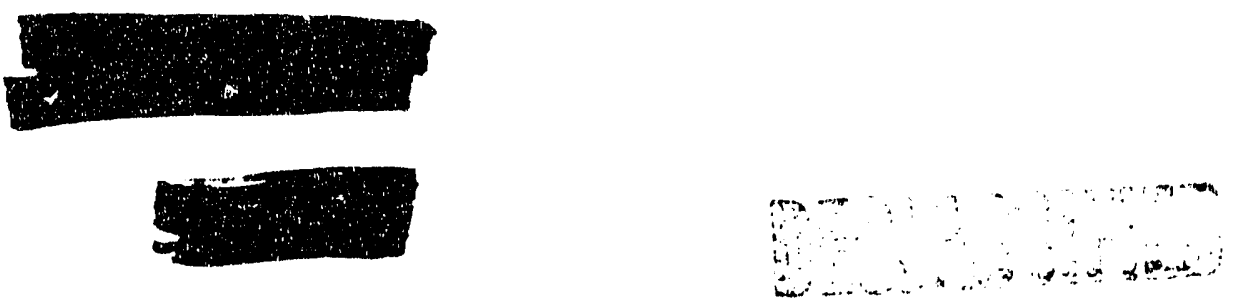


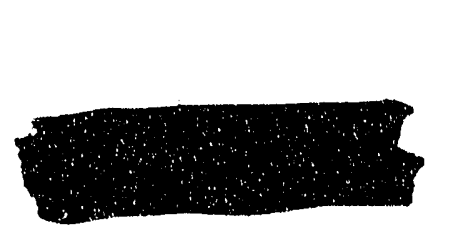

$H W 69074$ 八

Page 10

to Euarantee absolute control of radio-iodine emission. In adaition, they are relatively expensive.

The radio-iodine removal efficiency during dissolution of uranium irraliated at $10 \mathrm{Vri} / T$ Ton and cooled 90 days, must be mintained at greater than 99.95 percent et ourrent dissolution rates in order to kcop the radio-ionine emisoion bulow 10

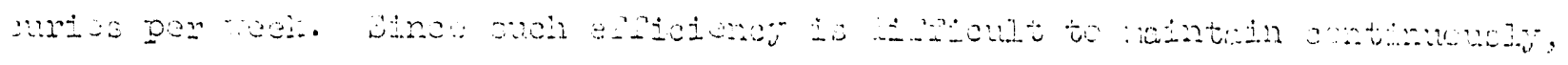

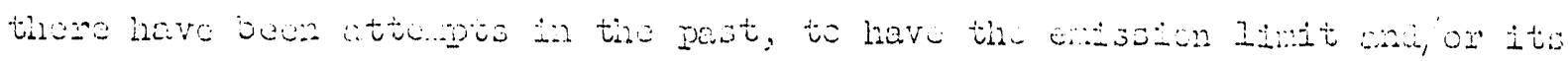

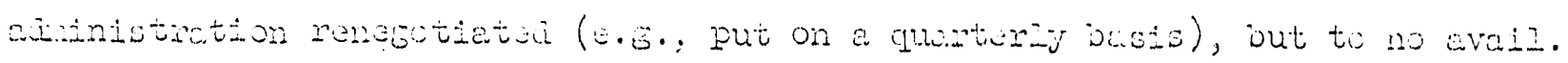

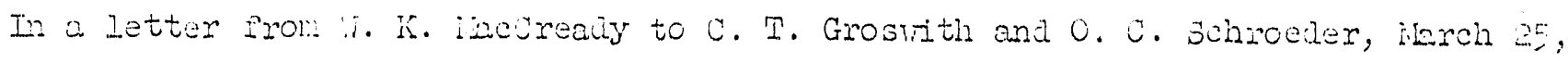
1957, it ves pointed out that "in asos where the operating continuity of a plent

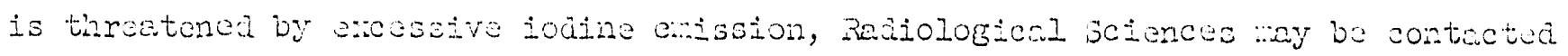
to detemine iz the concition o- the anvirons is such that the lo curie/ieel linit may be incressed. Where this is agreeable, Radiological sciences should provide mitten concurrence por our records". Although the radio-iodine emission has exceded the lo curie/reeli linit some je times since this letter vas rritten, there has never been mitten concurrence by Radiological Sciences.

Since there appears to be little hope for change or emission limit, and little hope or dependable erisision control ij thin the Iimit at reasonable cost using current or suscested methods, the most reasonable and most pronising solution to the radioiodine problen: is adational cooling time. Allowing the metal to cool 200 days

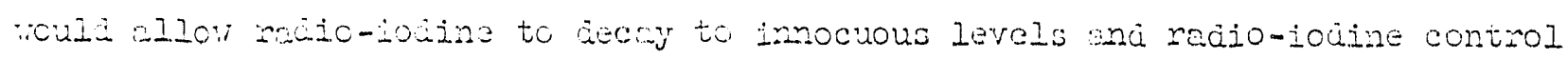
measures would not be requirca. Honever, any increase in the cooline time of the irradiated metal to be processed vill directly affect IPD and will require their concurrence. Some of the epfects of increesed cooling are estimated in Table IV. Bucket requirements are based on $\mathbb{H i}-64914(1)$.

(1) Hi-j4914, "Storsege Easin Eucket Requirements, CY-1.961", iG Albert, 4-26-60.
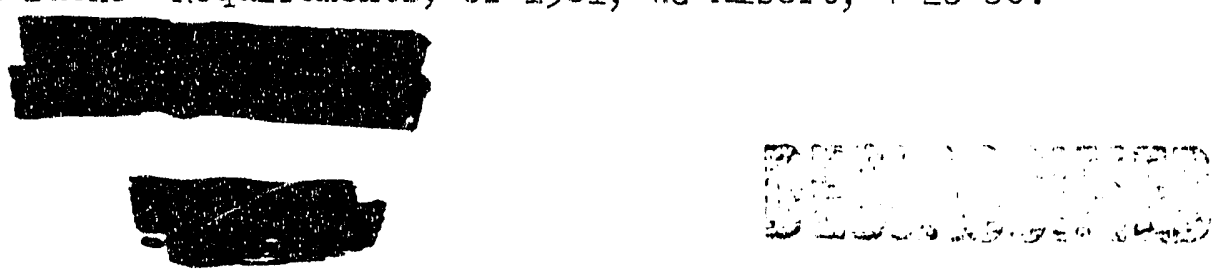


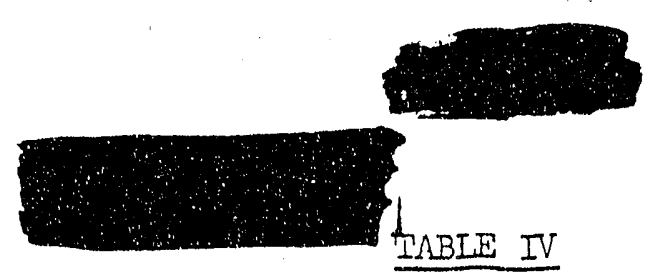

\section{HW 69064 h'}

Page 1$]$.

EFFECTS OF IITCREASED FUEL COOLING A ITER DISCHARGE FROM REACTOR

Cooling Tine

Buckets required for dumies, poison, tubing, etc.

Wstimated buckets raquired For metil stcroge

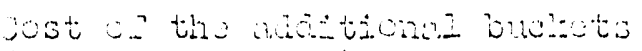

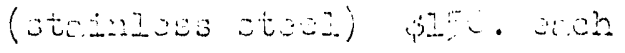

Tost of the aciational buclets

(Genranized) jio. each

Depleted metal in storare based

on 325 tons/inonth

T-metal in storage based on

75 tons/lionth
105 Days

120 Days

150 Days

200 Days

1865

1865

1865

1865

4210

1600

5300

5160

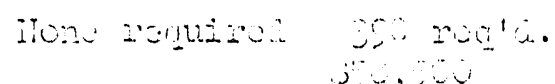

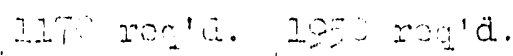

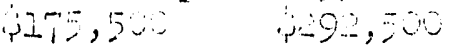

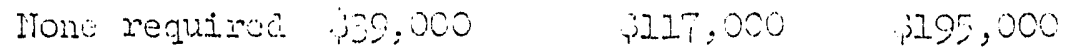

2010 tons

3125 vons

3750 tons

4790 tons

340 tons

375 tons 1,50 tons

575 tons

Accoraing to R.,i. Bom $(Z)$ the storage basins oi the eight reactors can store 7200 buckets, one row deep. E-netal must be stored only one row deep because of nuclear criticality consilerations; however, depleted metal may be double-stacled for storage. Fith up jo 200 days'cooling, no more than 40 percent of the storage space shoula be required for Emetal, dumies, poison, etc. The remaining space con store 4320 buclsets, single-stacked, or 8640 buckets, double-stackea. jtorage of the 4,790-ton inventory of depletea wetal vill require 5,322 buckets ( 0.9 ton/ buckat). It is apparent that at 200-day cooling, much of the depleted inventory

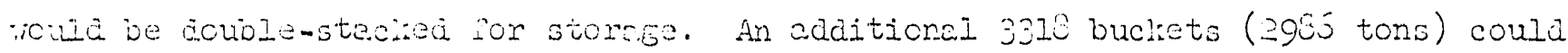
be stored, if requirea. Since this is appro:imately four months of reactor production, it is apparent that CPD vould have to be completely dom for four months before IPD Hould be forced to store metal in the basin aisles or elsevhere. (Consideration was brierly given to re-activation of the 200-iN, metal storage areas. Since each basin (2) Personal communication - R. I. Bown, 10-26-60.

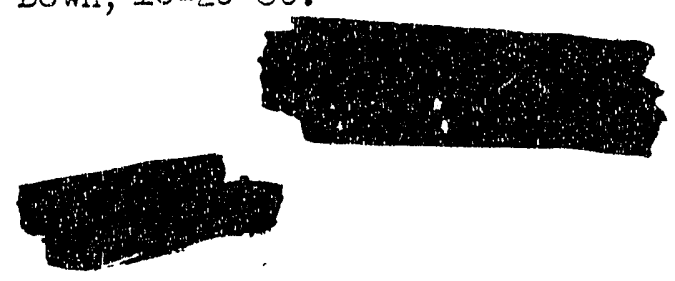




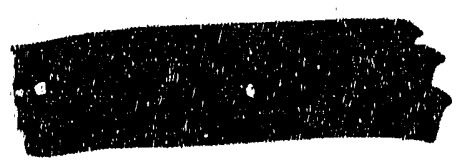

\section{HW 6906420}

Fage 12

at best, rould store only 120 buckets, sineie-stacked, or 360, couble-stacked, only si:: reeks of production could be stored in the three $200-11$ besins. This dia not appear to "xerront any adiftional stude, much less the expenditure of tunds ror recetivation on the $200-3$ basins.)

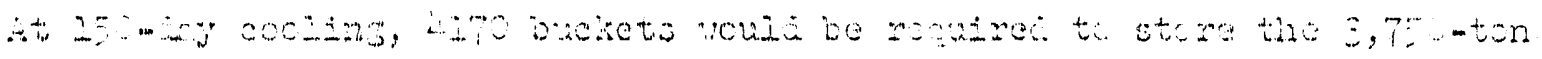

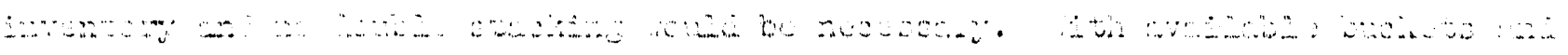

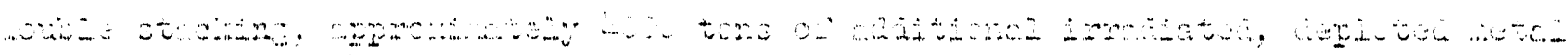

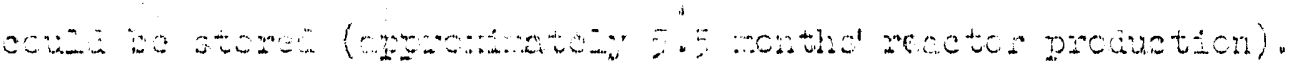

At $200-\mathrm{ag}$ a

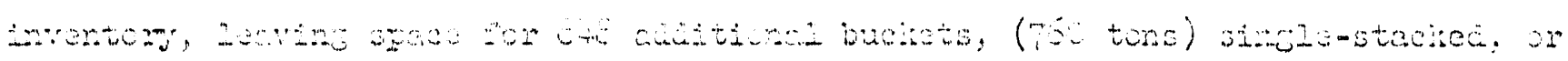

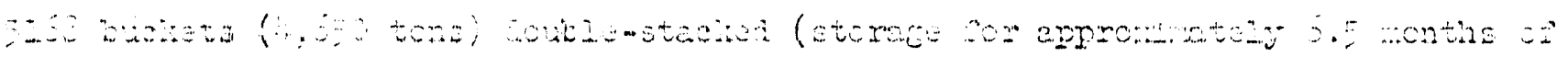

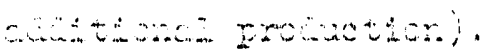

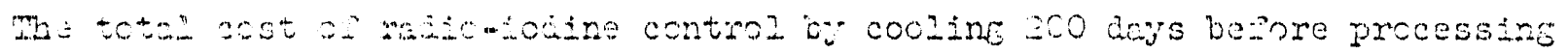

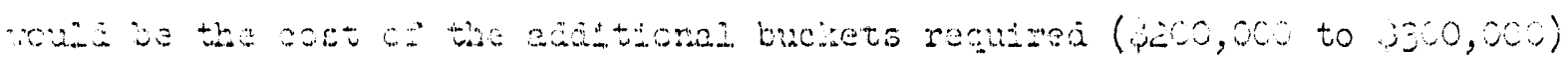

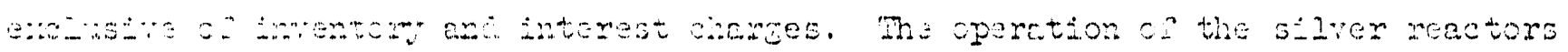

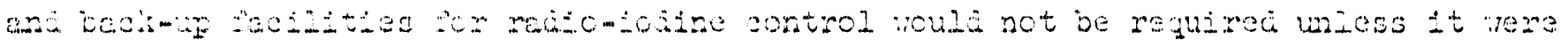

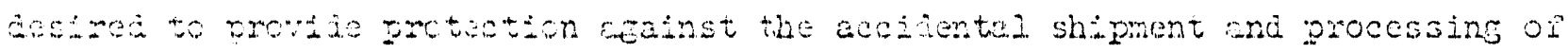
"rocen" netan.

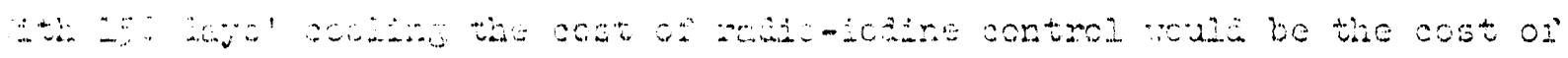

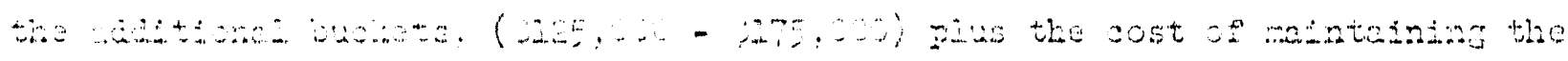

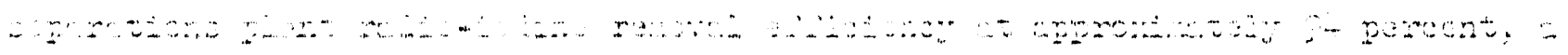

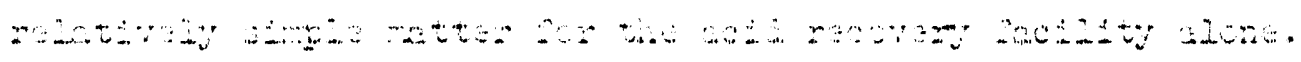

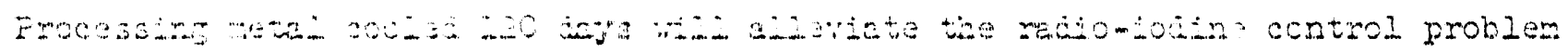

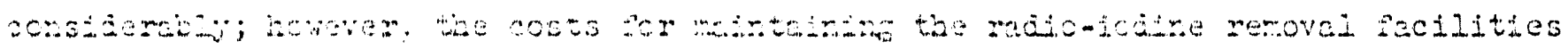

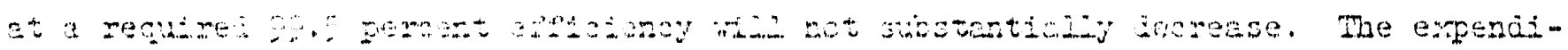

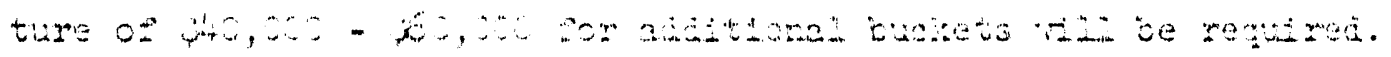

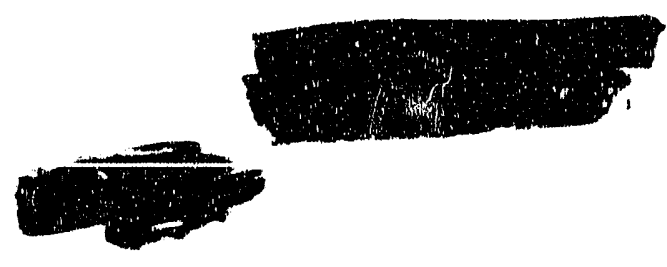




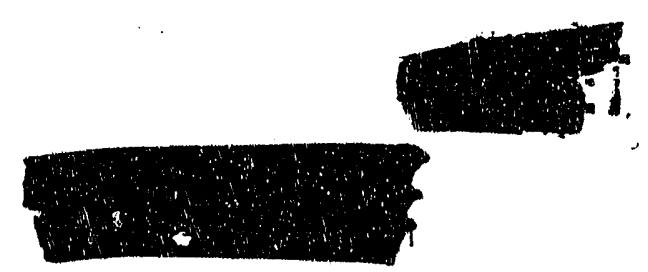

\section{Hib $6906-6 \Omega$}

Page 13

Future EAPO reactor progreme may affect the radio-icdine control measures required in CFD or conversely, OFP radio-iodine control problems may anfect the IPD reactor prograns. The FRTR aluminum-plutonium spike elements, to be pro-

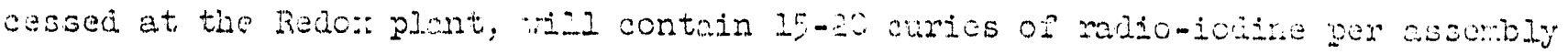

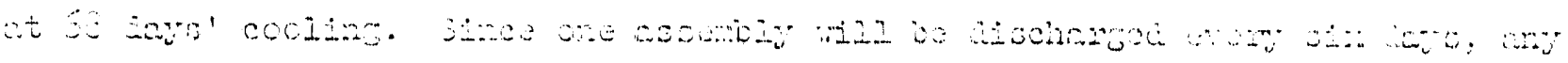

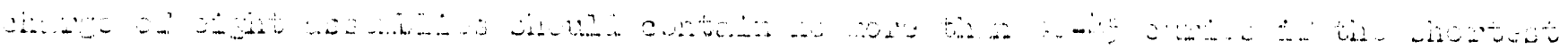

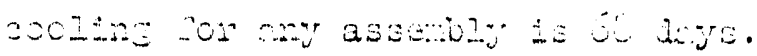

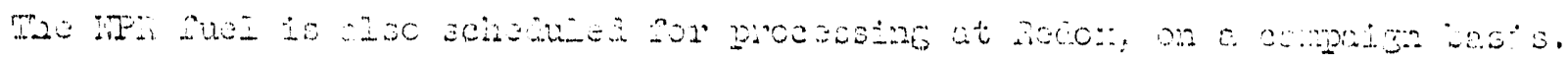

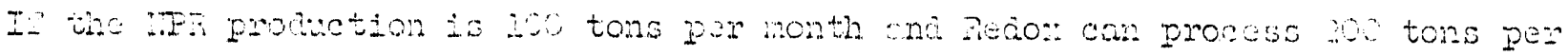

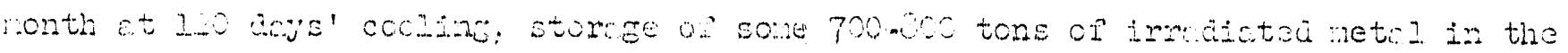

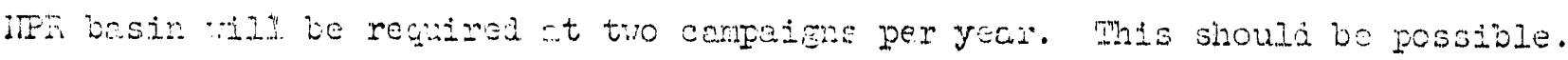

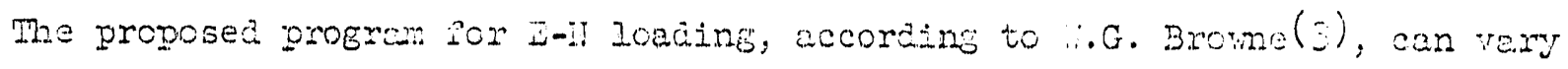
as Coljoris:

\begin{tabular}{|c|c|c|}
\hline & E-1stes & Depieted Wetal \\
\hline 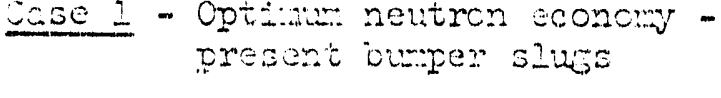 & 293 toms/yean & 5920 toms/yean \\
\hline Cese 2 - Blanitet locinge & 2650 tons/yaar & 6065 tons/year \\
\hline cose 3 - Fuld E-ii Icauing & 6714 tons/year & Itcre \\
\hline
\end{tabular}

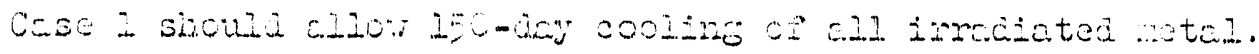

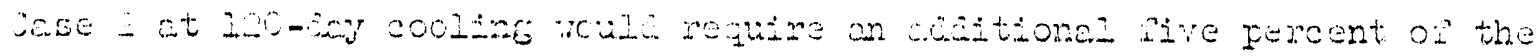

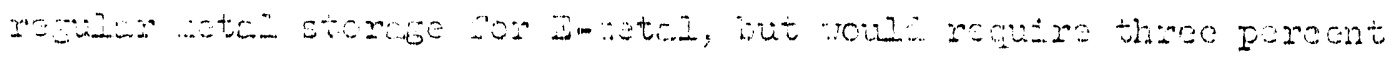

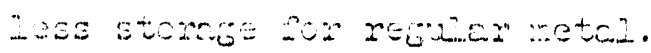

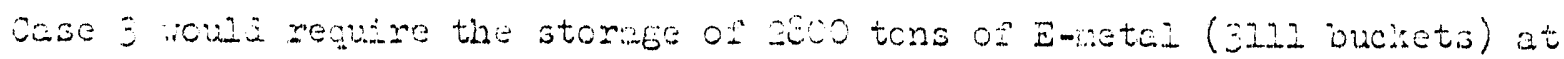
120 days' cooline. If CPD shouid be shut dom for three montho the availabie IPD storese iould be filled. (It is unciorstood that tho

(3) Personal comunicotion - ה.G. Brome, 12-it+-50.

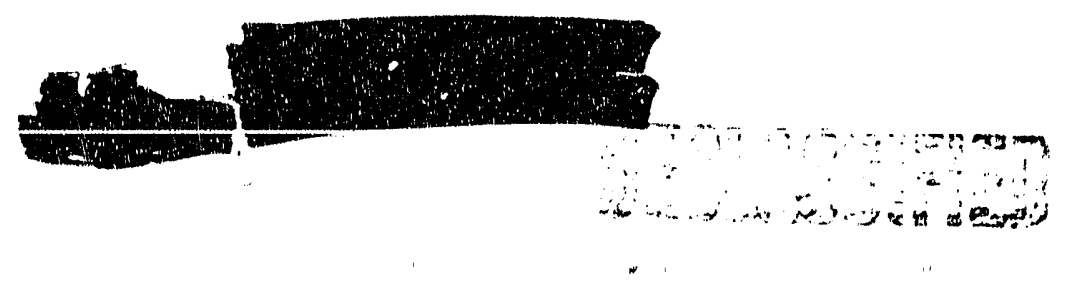


AEC is unoficially, not particu urly receptive to the E-il loading proerey and especially not to Case 3.) The Fure: plant vould be required to process Iminetal should vase 3 be acceptod.

The latest proposed procrom is the "over-ioore" progran. Under this procran:

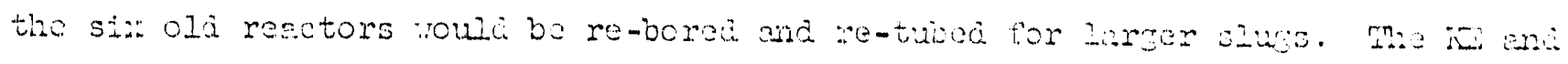

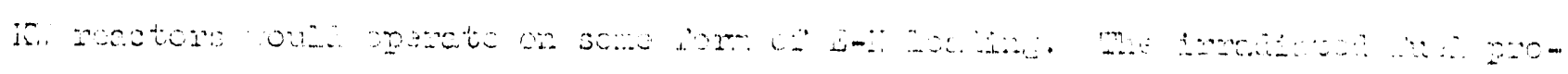

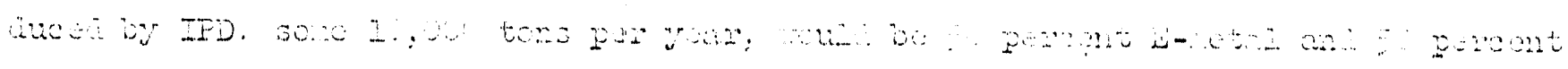

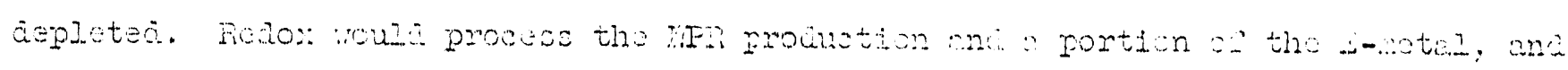

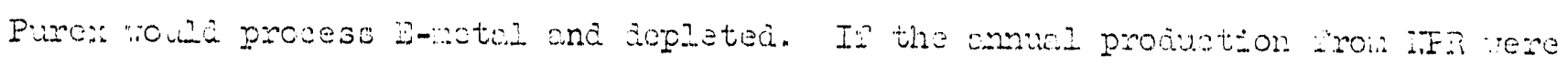

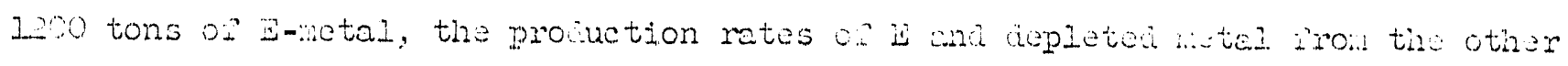

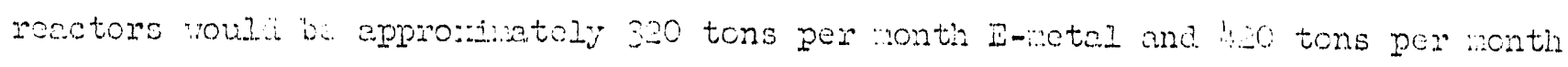

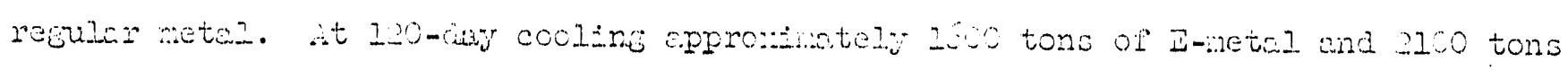
of depleted would be stored in the present recton" basins. In 75 percent of the basin capacity were svailable for storing irradiated enriched and depleted metal, 2542 single-stacked buckets woula be required to store the 2 -retal, ond 2333 bucl:ets for depleted. Double stacking of depleted buckets rould talre 1.157 bucket spaces. In al1, 3,700 bucket speces would be used, leavine 1691 in reserve $(75 \%$ of basin = 5400 spaces).

This reseme space ioula provide lag sucrage tor three wonths' adaitional proauction at las drys' cocline we four wonths', at go dus' cooline. Four months'

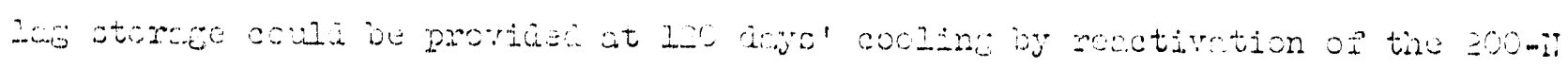

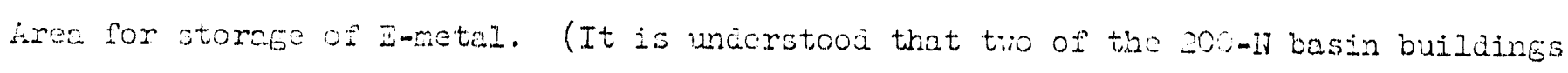
are in reasonable repain, but the tidida, used as a shop area, nould require extensive rehabilitation. Io cost estimates for re-activation of this area for metal storage are aveizabla.)
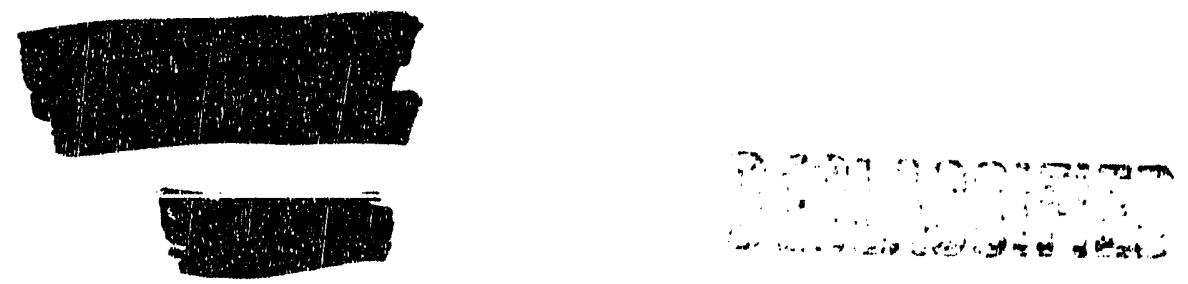


\section{SUSALAIY IID COICLUSICIS}

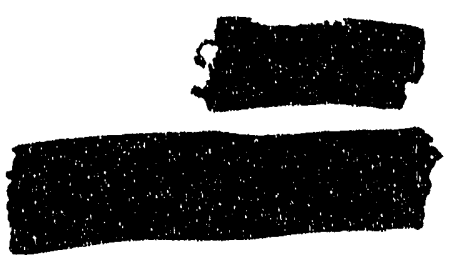

\section{HW $69074 \therefore ?$}

Page 15

1. Although CFD has spent more than 3 alilion dollars for radio-iodine control durlis the past five yass, effective control has not been attained. (Jurrently Furex is emitting $2-3$ curies per day while processing $95-$ iny-cooled actal.)

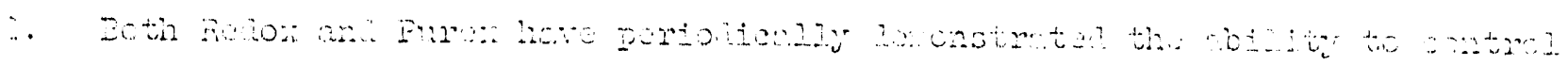

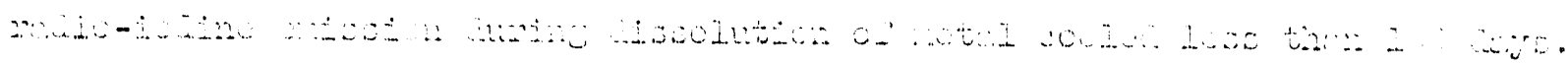

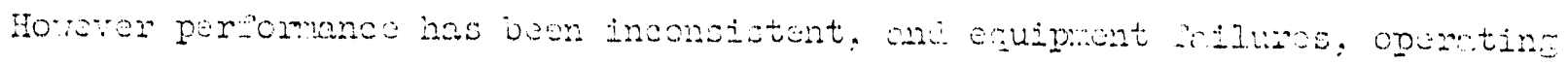

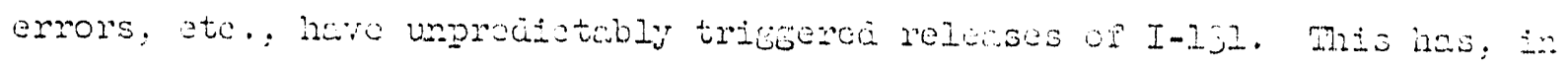

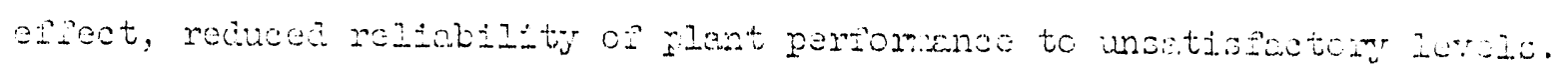
Theresore current control measures are unrolicble as vell as expensive.

3. The results oi etrict encorcment o: the radi-ionine emission limit wcuid probably be, (1) plant shutdorms anc decressea production, follored by (2) foilure to neet production commitments, and (3) increased capital ano. operatine costs with nore emphasis on maintencnce of silver renctors end other radio-iodine control equipment at top epriciency.

4. All of the altemate control measures currently envisioned ill ada to the cost for control, but only one w1l reelly provide a true increase in dependability oI control.

5. If control of the emission of radio-iodine is to be hela within the estabIished limit, increwsed cocine time appece to bo not only bhe checpest, but also the nost dependable nethod. The dupont Savannah River plant aissolves only metal cocled 150 days or more ond their former radio-iodine problems have disappeared. Since the supply of uranium is no longer critical, the principal objection to additional cooling ot the irradiated metal shoula be gone.
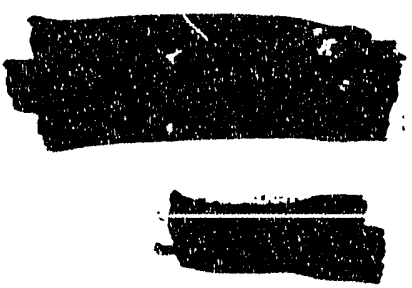
Therefore, with the cocperation and concurrence of IPD, it is recomalended that 150 days be established by SPD as the normi cooling time, ritin I

as the minimum acceptable. This should be made subject to renogatiation as necessitated by chonges in porer levels, profrms, or other conditions arocting Liner aepertinnt.

\section{DISCLAIMER}

This report was prepared as an account of work sponsored by an agency of the United States Government. Neither the United States Government nor any agency thereof, nor any of their employees, makes any warranty, express or implied, or assumes any legal liability or responsibility for the accuracy, completeness, or usefulness of any information, apparatus, product, or process disclosed, or represents that its use would not infringe privately owned rights. Reference herein to any specific commercial product, process, or service by trade name, trademark, manufacturer, or otherwise does not necessarily constitute or imply its endorsement, recommendation, or favoring by the United States Government or any agency thereof. The views and opinions of authors expressed herein do not necessarily state or reflect those of the United States Government or any agency thereof. 



$$
\text { HIS } 390964
$$
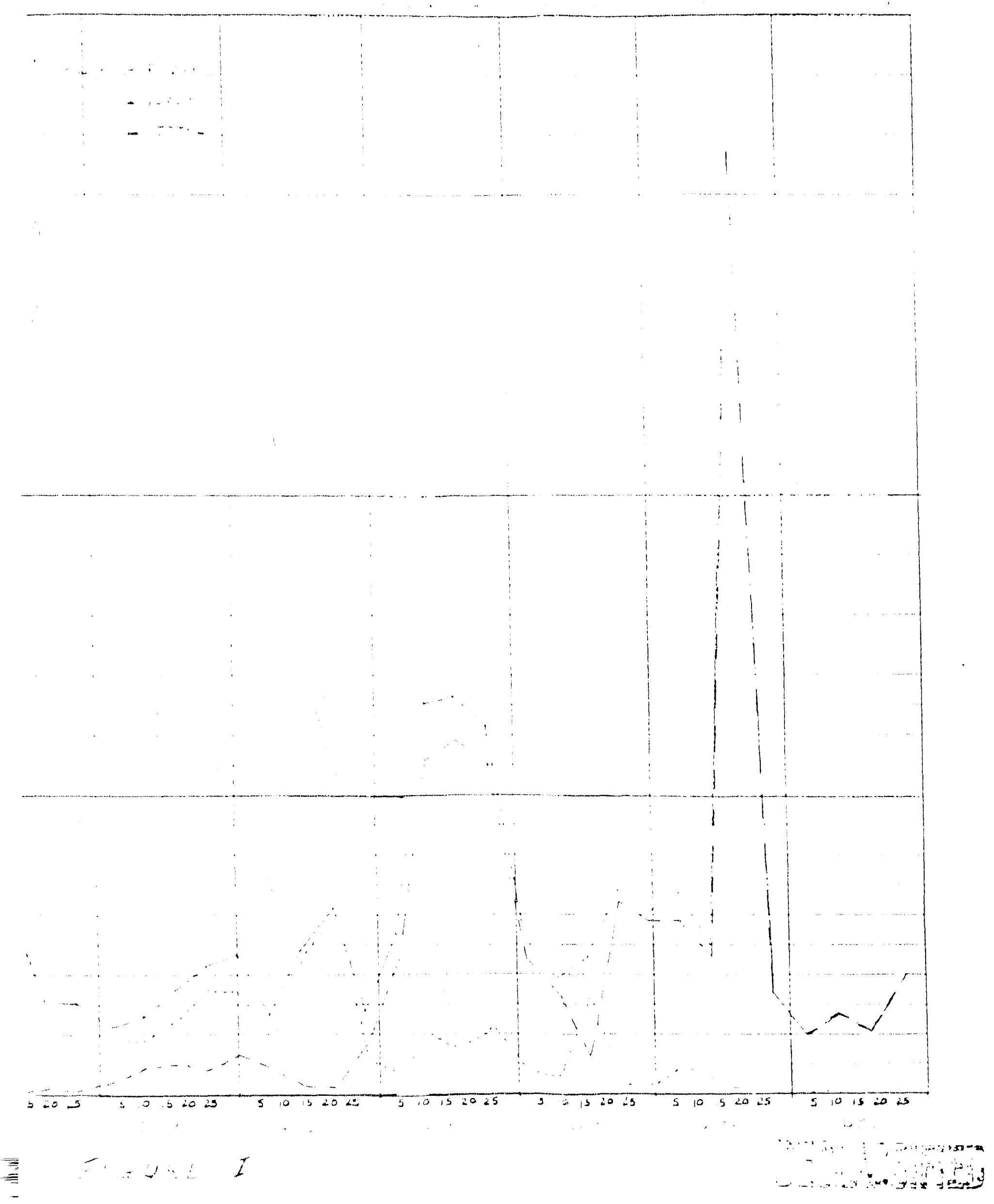


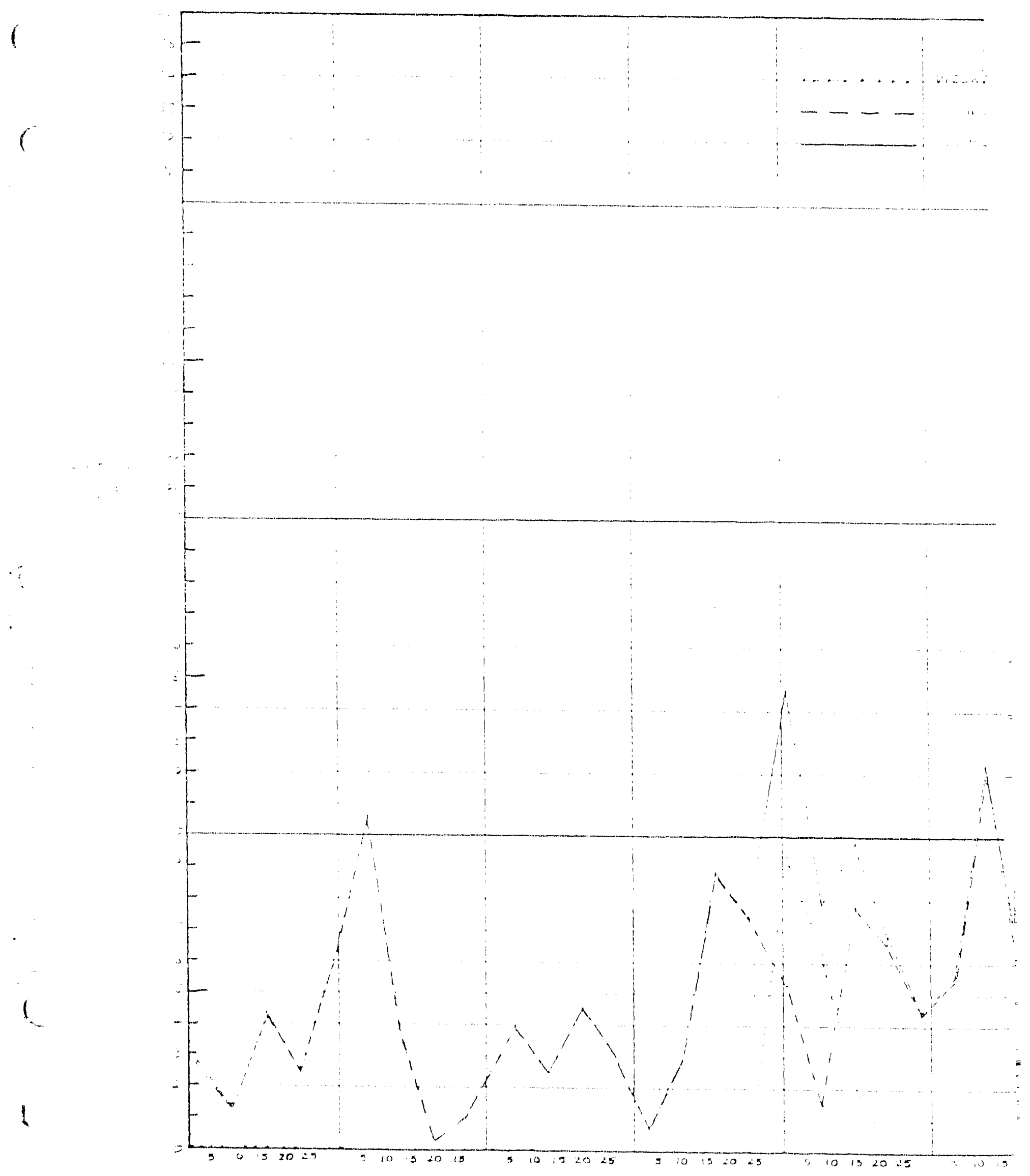


Hit $6900=$

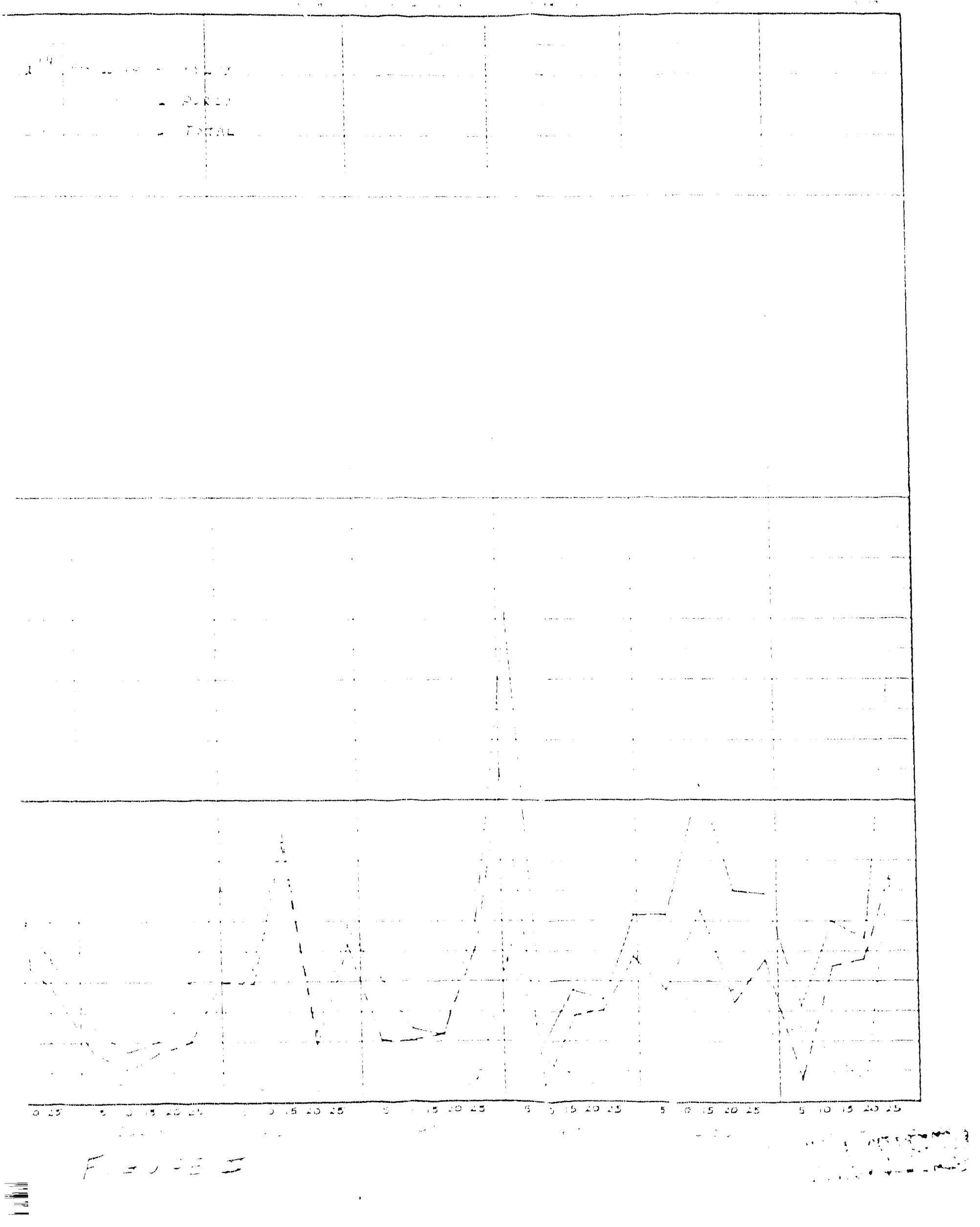




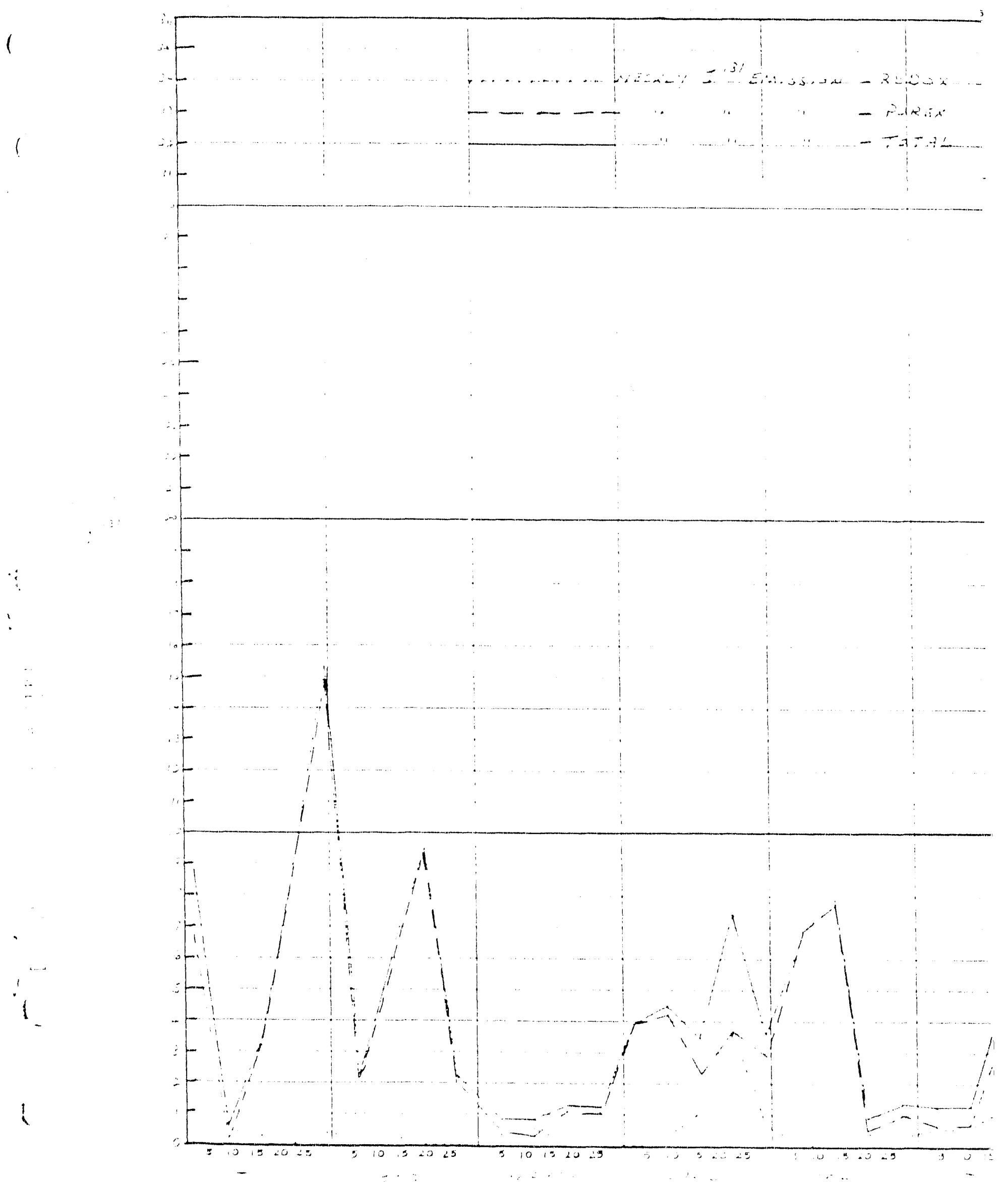




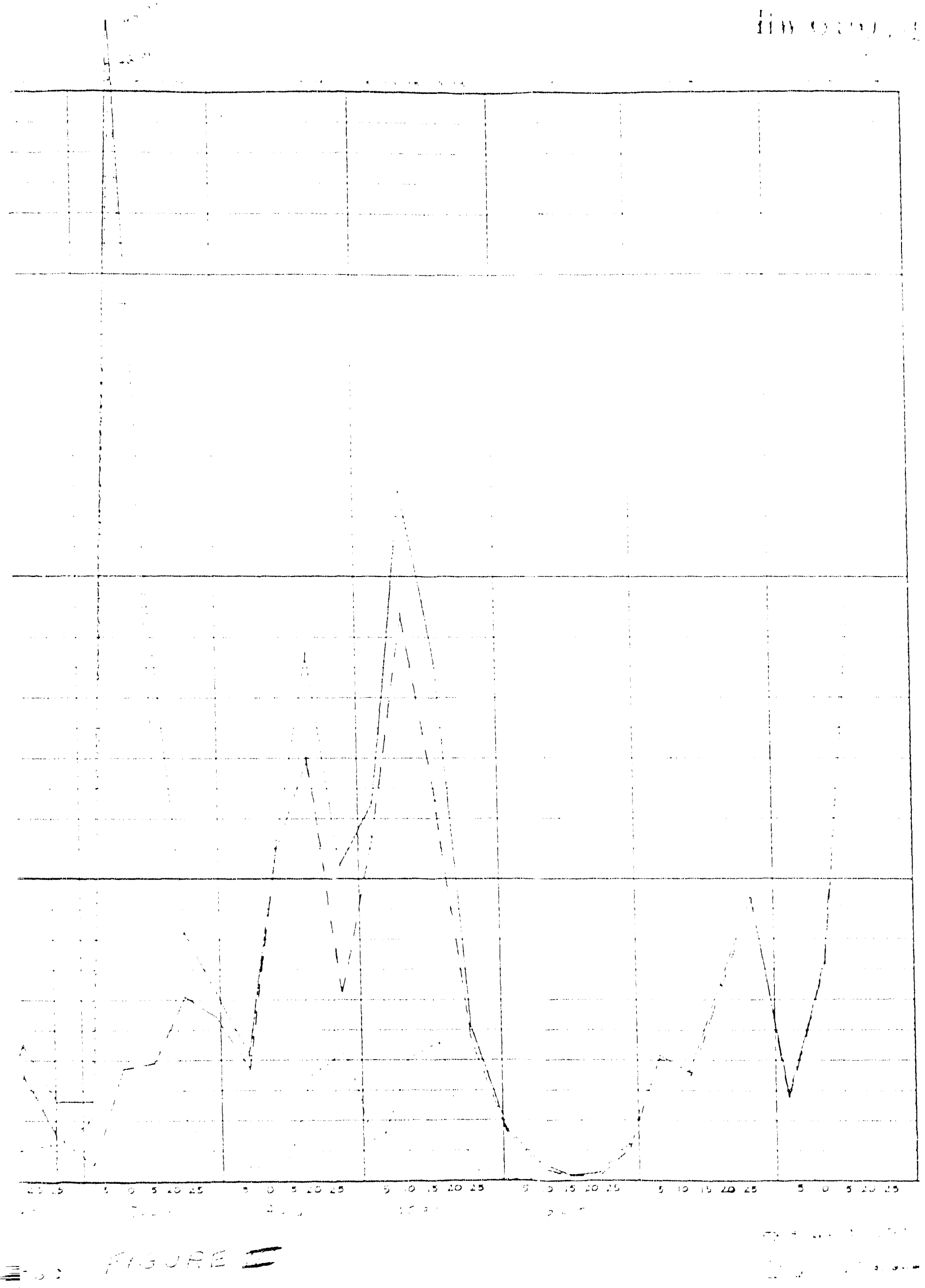



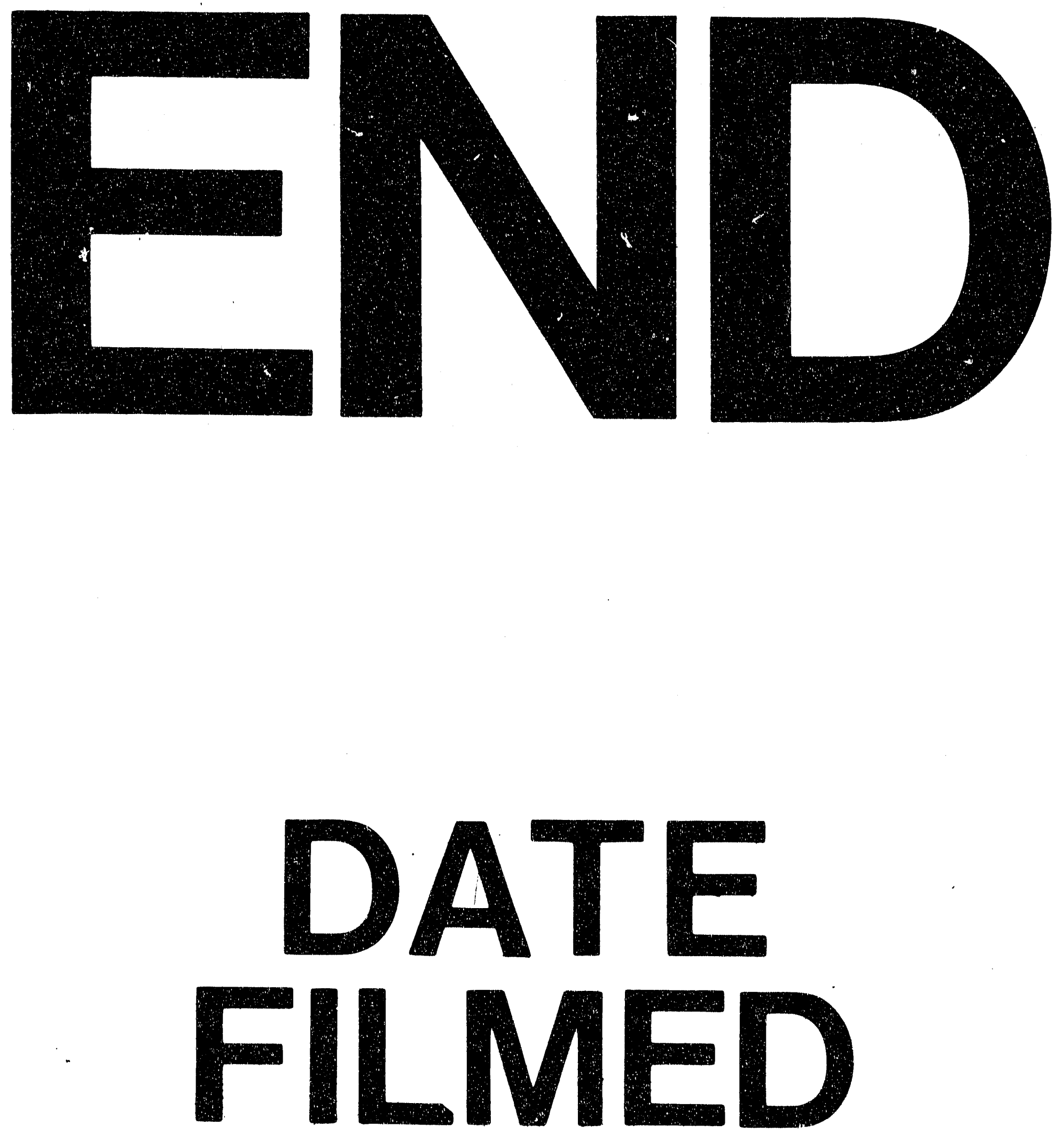

点

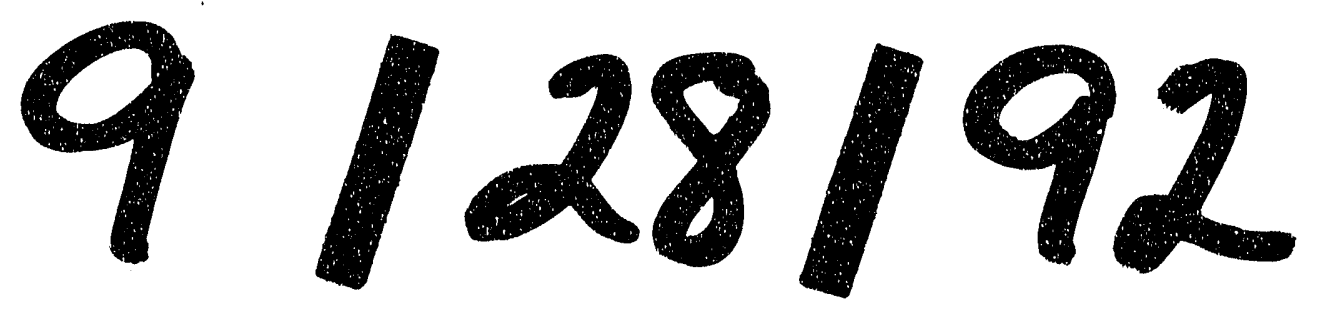


